\title{
Promoting process approach to management
}

\author{
Emília Papulova ${ }^{1 *}$ \\ ${ }^{1}$ University of Economics in Bratislava, Faculty of Business Management, Department of \\ Management, 85235 Dolnozemská 1, Bratislava, Slovakia
}

\begin{abstract}
Increasing environmental dynamics and deepening competition are forcing businesses to seek effective responses and, within them, appropriate management approaches to be competitive and succeed in the market. The process approach, which in recent years has become an integral part of managerial practice in the company, emphasizes the business processes. Focusing on processes and improving them in companies is an effort to better respond to changing customer requirements. This paper deals with the possibilities of applying and using methods and techniques to support the business process management in companies and deals with the essence and benefits of individual methods to support the performance and competitiveness of a company.
\end{abstract}

\section{Introduction}

Business process management (BPM) based on process orientation of companies is not a new approach however many companies are still struggling with it application. BPM is often presented as a systematic managerial approach enables organization's workflow to be more effective, more efficient and more capable to adapt to an ever-changing environment.[1] In relation to the changing nature of the environment brings advantages in relation to the functional approach. Process approach offers new opportunities for companies from the view of increasing the performance and competitiveness of businesses. The advent of a process approach raises a shift in the concept of thinking, which represents a shift from division of labour, specialization and functional orientation towards the integration and business orientation of processes.

The goal of the article is to introduce and evaluate individual methods and techniques in terms of their application in the process management of a company and to point out their benefits for increasing the competitiveness and success of companies operating in a changing environment. As it is confirmed by researchers [2], praxis of the companies suggests that BPM methods indirectly contribute to process performance by establishing a BPM culture and that the correct application of methods yields direct performance benefits.

Methodology of the work is based on the analysis of theoretical knowledge and starting points in the field of process management, evaluation of individual methods and approaches usable in the management of process-oriented organization and based on the results of

\footnotetext{
*Corresponding author: papulova@euba.sk
} 
existing research in this field. applicability of individual methods in the process management of the organization.

\section{Process approach to management}

\subsection{Theoretical frameworks of knowledge about BPM}

Today we are seeing a shift from an industrial society to a knowledge society. This shift has also led to changes in the way of thinking and approaches to business management.

Enterprises in an industrial company were characterized by their focus on achieving a competitive advantage, through the rapid introduction of new technology and technology, investment and improved asset management. Organizations in the knowledge-based economy are characterized by a different concept of thinking, a concept in which success depends more on the ability to mobilize and exploit intangible assets.

In order to ensure success over the long term, today's businesses are trying to meet the customer's requirements in the best and fastest possible way and to adapt their processes. Focusing on processes, their rational course and improvement with the aim of flexibly responding to changing customer requirements is the basic idea on which the process approach is built as a new concept of BPM. BPM is an approach used to manage business processes by facilitating the modelling, the execution as well as the improvement of a processes of organization and is considered as the most appropriate approach to continuously improving processes. [3]

Process-oriented company emphasizes in particular: [4,5]

- customer orientation, monitoring and adaptation to changing customer requirements, creating an immediate relationship with the customer and his loyalty

- focus on processes that are dependent on the customer and his needs

- product and service innovation, providing high quality customer-oriented products at affordable prices

- teamwork, quality, engagement and dedication of people in the team for continuous improvement of processes, continuous learning

- business process management systems using methods and approaches to support process efficiency with IT support for process management.

- a corporate culture that fosters interest in continuous process improvement, responsibility sharing.

The purpose of the transition from a functional hierarchy to a process-oriented organization is to support customer orientation and the organization's performance and competitiveness. The essence of the change is to replace the focus on functional units in the company system by focusing on business processes. The goal is to break down barriers between functional areas to promote organizational flexibility and value for the customer. Process organization is built on the principle of integration of activities into integrated processes provided by process teams.

\subsection{Current methods and approaches to support the process approach to management}

The focus of the process approach is on the business processes. The process approach is focused on the preparation and design of processes in the company so that they run efficiently and create maximum value for the customer. Several methods and techniques can be used to support the process approach: 
- in the area of process improvement and product quality can be used methods from Total Quality Management through Lean Management to Six Sigma.

- in the field of process optimization and modelling, building business process architectures and defining business success metrics can be used Porter value chain methods, Business Process Reengineering, Business Process Redesign, Balanced Scorecard, Activity Based Management.

BPM requires a deeper understanding of the possibilities of using different tools and methods. Selection of methods should be connected to the organization's requirements and conceptions, but also to the skills and abilities to use the tool. [5] IT-supported methods and techniques create significant potential for improving process and management of the whole company.

\subsubsection{Total Quality Management}

Total quality management (TQM) is a comprehensive quality management approach that aims to ensure high product and service quality for maximum customer satisfaction.

The method assumes that the company is process oriented [4] and is based on philosophy of continuous process improvement, which begins with prevention, aimed at preparing quality inputs and production and management systems, which according to the author of this method, E. Deming, supports the idea of "quality needs to be built into the product." [6] It means constantly looking for ways to improve product quality and ensure minimum or zero error rates. Employees and their commitment and involvement throughout the process play an important role in the whole approach.

\subsubsection{Lean Production and Lean Management}

Lean production is considered to be a business philosophy that aims to reduce time between customer and supplier by eliminating wastage across the enterprise supply chain. It is not just about reducing costs but, above all, maximizing the value of the product for the customer. Slimming is the way to produce more, have lower overheads, use our areas and production resources more efficiently. Lean production cannot work without a close link to product development and production engineering, logistics and business management. [7]

Lean management is an approach where the concept of lean presents an effort to eliminate any losses and waste and reduce the costs of the company. The principles of slimming have gradually expanded from production to other areas, including the whole company. Some authors considered the main of Lean Management has become the reduction of all types of waste, like in transport, inventory, traffic, waiting, processing, etc. [8]

Lean management is a comprehensive approach aimed at maximizing customer value. The fulfillment of this goal is based on process-oriented production based on customer requirements, on the integration of suppliers and customers into the value creation chain and teamwork - process teams that are guided and motivated to create the highest value for the customer.

\subsubsection{Six Sigma method}

Six Sigma is focused on continually innovating and improving processes, reducing deviations and improving product quality and business profit growth by approaching all processes in the business to be defined, measured, analysed, improved and controlled. 
In practice, the Six Sigma method is developed into the DMAIC model, which represents methodology to implement the Six Sigma method for improving processes in the company. [7] This methodology includes the following basic stages:

- D (Define) - the stage of defining a problem, which present aspects of the process or product that negatively affect customer satisfaction and business performance

- M (Measure) - stage of measurement and acquisition of objective data, which express the current state and achieved results

- A (Analyze) - stage of data analysis, identification of key causes of defined problems and based on analysis to identify possibilities of improvement

- I (Improve) - a stage in which the process is modified to provide key solution parameters to be accepted by the customer

- C (Control) - the aim of the stage is to evaluate the results of implemented solutions, whether they have a lasting effect and there are no other negative impacts.

The Six Sigma method is a metric method based on the analysis and using empirical data, quantitative measures for evaluating business objectives, where the basic measure is the number of defects, or deviations, resulting in lower customer satisfaction, increased costs and reduced business profit. Statistical evaluation and standard deviation are used statistical average and statistical deviation. The quality standard is set at a level that the business process must not produce more than 3.4 defects per million cases. [9]

\subsubsection{Value chain approach}

The perception of the transformation process in the company in its physical form is based on the perception of its material flow in the company, the movement of labour and capacity resources to ensure the course of activities so as to create products that can be placed on the market. Each of these activities, within the involvement of the defined resources, contributes to the creation of costs and participates in the creation of values and added value in the company. And here we come to perceive the transformation process as a value-creating process.

In an illustrative way, the process of value creation in the company and the share of individual activities in the creation of added value is expressed by M.E.Porter using the "value chain". The value chain encompasses a set of all related activities, from raw materials and materials processing to handing over the product to the customer and expresses how individual business activities contribute to value creation.

When analysing the value chain, we distinguish two basic groups of business activities, namely primary and secondary activities. The primary (basic) activities are arranged in the direction of material flow in the company. The performance and results of primary activities in the company depend on the course and involvement of secondary (support) activities. [10]

Value Chain Management is the process of managing the flow of integrated activities and information in a product flow with the aim of achieving efficiency, or greater value for the customer. [9]

\subsubsection{Business Process Reengineering}

Business process reenginiering is defined by Hammer and Champy as a fundamental reassessment and radical reconstruction of business processes so that dramatic improvements in critical performance measures such as cost, quality, service and speed can be achieved.

Business process reenginiering does not mean incremental changes and improvements in business but represents an endeavor to abandon existing practices and to look at new 
perspectives on the processes necessary to create products and services to meet customer needs. The idea is to find new and better solutions and ways of working. Business process reenginiering encompasses a range of changes, abandoning existing and established practices and changing work in terms of content and organization. It is important that changes are initiated from the customer and their needs, hence the new process design. Not only top executives are involved in this challenging plan, but it is important that other employees participate in it with their commitment, interest, creativity and willingness to succeed. [9]

The main expectations of fulfilling this goal include the ability to flexibly respond to customer requests, reduce under-sales, eliminate sources of errors and deficiencies, and improve quality, eliminate non-value-generating activities, reduce time and reduce overall business costs.

\subsubsection{Balanced Scorecard}

The Balanced Scorecard concept, commonly referred to as a strategic system for managing and measuring business performance, can also be used to support process management. This concept is used in practice to provide managers at all levels of business management with information about the activators, or drivers of business performance, and their statuses that affect business success. It is considered as a management system that provides a ground for businesses to clarify the vision and strategic plans and convert them into action with sufficient feedback about both internal processes and external business outcomes. [11]

The BSC approach structures business management issues into four areas or perspectives, namely: [7]

- financial perspective - through financial indicators that give a view of the company from the perspective of its owners

- Customer perspective - using indicators that present the customer's expectations and perspective

- process-organizational perspective - defines processes that are critical to customer satisfaction, focuses on their improvement, evaluation and measurement of their effectiveness

- Learning and growth perspectives - through the characteristics that a business must have for sustaining strategic goals in response to changes in the external and internal environment.

Since BSC is focused on managing the business according to the set goals and objectives, it is then important for strategic goals of the business to identify critical success factors that are further elaborated from the perspective of these four perspectives and define the links between them as well as evaluation of success.

The BSC monitors the interrelations and connections between the basic perspectives perspectives, thus ensuring the link between strategy and business processes, as well as linking to the financial, customer, learning and growth perspectives. A prerequisite for the implementation of the BSC is a clear understanding of the organization's vision and strategy. The goal of organizational integration of Balanced Scorecard is its integration with management and reporting. [4]

The BSC concept thus provides business managers with the necessary information and insights to better understand goals, results, relationships, cause-effect relationships, activators in relation to financial and non-financial indicators.

Correctly understood and implemented Balanced Scorecard method brings to businesses numerous benefits. It serves as a support for implementing business strategy, it strengthens cooperation between business units, business departments, human resources of a businesses 
and it serves as a communication tool in a business. Another important benefit is orientation of managers on key customers and partners and improvement of relations with business stakeholders. [12]

\subsubsection{Activity Based Management}

Activity Based Management (ABM) was created by the improvement of the activitybased costing $(\mathrm{ABC})$ method. Research proved that $\mathrm{ABC}$ and process modelling provide a good starting point in heading toward more cost-conscious design and help organization to learn the relationships between the activities performed in the organization and their associated costs [13]

$\mathrm{ABM}$ is a comprehensive cost management system that provides information from a wide range of business activities. It is an approach aimed at managing and evaluating processes in a company and identifying their strengths and weaknesses. This methodology is a comprehensive cost management system that provides information from a wide range of business activities thus becomes a source of information that has hitherto been hidden, creating room for better decision-making in the organization. [4]

The ABM methodology is based on a customer-oriented philosophy of process thinking and includes: [7]

- Identification of business activities from perspective of business processes and their hierarchy

- Measurement of performance, calculation of costs for individual activities

- Looking for ways to improve the overall value chain from product design, through production, sales to direct debit, continuous process improvement.

The essence of this approach is thus to constantly search for activities that need to be eliminated because they are unproductive and activities that need to be strengthened because they can contribute to increasing the profitability of business.

\section{Further routing in the field of process approach}

Increasing competition leads businesses to seek new innovative approaches, implement new equipment and workflows where people's work is being replaced by machine-driven computers. Integration of information technology into managerial work promotes closer interconnection of the company and its processes with the customer, the ability of managers to make quick and high quality decisions, ensure synchronization of business processes and thus reduce costs and increase efficiency, to ensure timely delivery of products and services that will be of value to the customer. [9]

Artificial intelligence is a science that seeks to simulate intellectual thinking using information technology. At the interface of informatics and biology, it offers tools that simulate various aspects of the world of living organisms by means of computer technology, such as. brain function. By means of these procedures it is possible to find solutions to various optimization or decision problems. [14]

The benefits of introducing process management in companies can be seen from operational, market and strategic aspects. Operational and strategic benefits are associated with benefits for an organization that has decided to look at its operation from a procedural perspective and actively approach process management. In the area of market benefits the positive aspects of process management on the part of the customer are included.

Process approach and BPM concepts have matured over the years and new technology, concepts, standards, and solutions appear. Recent trends of development in the context of process approach to management developments are in particular: [4,16,17]

- focus on development of process specialists and creation of qualified process teams, 
- focusing more on process efficiency and innovation (moving away from focus on efficiency);

- creation of suitable organizational culture suitable for application of process management,

- integrating business applications and focusing on a user-friendly, user-friendly page

- use of social networks and mobile interfaces to support process management, using not only external social networks (such as Facebook and Twitter), but also internal networks such as SharePoint, etc. (Social \& Mobile BPM Solutions)

- use of intelligent systems that enable the company to proactively adapt to changing market trends (iBPM - smart BPM solutions),

- use of cloud solutions (Cloud BPM solutions),

- the use of Gamification of BPM concepts and techniques.

- robotic process automation and opportunities connected to Industry 4.0.

New technologies and concepts such as automation, system integration, autonomous robotics, digitization, Internet of Things, artificial intelligence systems are also implemented in approaches and methods of BPM.

\section{Conclusion}

The concept of process organization and process management puts the integration of work at the center of managers' attention to bring the expected synergy effects and thus support the organization's performance and competitiveness. However, this concept also imposes new requirements on managerial work, the mastery of process philosophy, clear customer orientation and knowledge management supported by continuous learning of employees at all levels of management.

There are various BPM methods that contribute to process performance by establishing a BPM culture and lead to performance benefits.

Trends of the last phase of process management development are mainly focused on software solutions and IT support of application of process management and trends connected to Industry 4.0.

This article is a partial output of research project VEGA no. 1/0017/20 entitled Changes in the application of managerial functions in the context of the fourth industrial revolution and the adaptation processes of enterprises in Slovakia.

\section{References}

1. A. Gažová, Z. Papulová, J. Papula. The application of concepts and methods based on process approach to increase business process efficiency, Procedia Economics and Finance, 39, 197-205 (2016) https://doi.org/10.1016/S2212-5671(16)30284-2

2. T. Schmiedela, J. Reckerb, J. Brockec. The relation between BPM culture, BPM methods, and process performance: Evidence from quantitative field studies.

Information \& Management, 57, 103-175 (2020) https://doi.org/10.1016/j.im.2019.103175

3. K. Mehdouania, N. Missaoui, S. AyachiGhannouchia. An approach for Business Process Improvement Based on Simulation Technique, Procedia Computer Science, 16, 225-232 (2019) https://doi.org/10.1016/j.procs.2019.12.176

4. Z. Papulová, A. Oborilová, J. Papula. Procesný manažment ucelený pohl'ad na koncepciu procesného manažmentu (Kartprint, Bratislava, 2014) 
5. A. Oborilová, Z. Papulová, Business process management and its implementation in Slovak enterprises, Comenius Management Review, 5, 4-13 (2011)

6. Š. MARSINA et al. Management (EKONÓM, Bratislava, 2007).

7. J. Řezáč, Moderní management. (Computer Press, Brno, 2009. 397)

8. R. J. Schonberger, The disintegration of lean manufacturing and lean management, Business Horizons, 62, 359-371 (2019) https://doi.org/10.1016/j.bushor.2019.01.004

9. S.P. Robbins, M. Coulter, Management. (Pearson Education Limited, London, 2016

10. J. Papula, Z. Papulová, J. Papula, Strategický manažment. Aktuálny concept pre rýchlo sa približujúcu budúcnost', (Wolters Kluwer, Praha 2019).

11. R. S. Kaplan, D. P. Norton, D. P. Balanced Scorecard (Management Press, Praha, 2007)

12. L. Lesáková, K. Dubcová. Knowledge and Use of the Balanced Scorecard Method in the Businesses in the Slovak Republic, Procedia - Social and Behavioral Sciences, 230, 39-48 (2016) https://doi.org/10.1016/j.sbspro.2016.09.006

13. K.Tornberg, M. Jämsen, J. Paranko. Activity-based costing and process modeling for cost-conscious product design: A case study in a manufacturing company, International Journal of Production Economics, 79, 75-82 (2002) https://doi.org/10.1016/S09255273(00)00179-1

14. M. Jakubéci, Využitie prostriedkov umelej inteligencie na akciových trhoch. (Dizertačná práca. Bratislava, Fakulta managementu UK, 2015)

15. M. von Rosing et al., Business Process Trends, The Complete Business Process Handbook, Elsevier, 1, 187-216 (2015)

16. T. Grisold et al. Exploring Explorative BPM - Setting the Ground for Future Research, BPM 2019: Business Process Management, Springer 11675 23-3 (2019)

17. J. Papula et al. Industry 4.0: preparation of Slovak companies, the comparative study. EAI/Springer Innovations in Communication and Computing, 1, 103-114 (2019) 